\title{
Socioeconomic Development, Demographic Dynamics and Forest Fires in Italy, 1961-2017: A Time-Series Analysis
}

\author{
Margherita Carlucci $^{1}$, Ilaria Zambon ${ }^{2} * * \mathbb{D}$, Andrea Colantoni ${ }^{2}{ }^{\mathbb{D}}$ and Luca Salvati ${ }^{3}$ \\ 1 Department of Social and Economic Science, University of Rome La Sapienza, Piazzale A. Moro 5, \\ I-00185 Rome, Italy; margherita.carlucci@uniroma1.it \\ 2 Department of Agricultural and Forestry Sciences (DAFNE), Tuscia University, Via San Camillo de Lellis, \\ I-01100 Viterbo, Italy; colantoni@unitus.it \\ 3 Council for Agricultural Research and Economics (CREA), Viale Santa Margherita 80, I-52100 Arezzo, Italy; \\ luca.salvati@crea.gov.it \\ * Correspondence: ilaria.zambon@unitus.it
}

Received: 15 January 2019; Accepted: 22 February 2019; Published: 1 March 2019

\begin{abstract}
Empirical studies investigating long-term trends in wildfires' frequency and severity have been relatively scarce in Europe. Number of fire events, total burnt area and average fire size were studied between 1961 and 2017 in Italy with the aim to identify homogeneous time periods with similar wildfire frequency and severity and correlate them with the background socioeconomic context. Fire attributes had a diverging behavior over time: the number of fires was the highest in the 1970s and the early 1980s; total burnt area was relatively more constant over time with a peak in the 1980s; and, finally, average fire size decreased quite homogeneously from the peak observed in the 1960s and early 1970s. The number of fires and average fire size were significantly influenced by the value of the same variable one year before. Investigating long-term historical outlines of forest fires, a mixed approach based on time-series statistical analysis, multivariate techniques and regressive models intended to define changes in fire regimes and socioeconomic development. In fact, the comparative valuation of the socioeconomic aspects and wildfire trends can reveal a key step to recognizing mitigation and preventive possibilities. Through a multivariate analysis, a substantial difference in the socioeconomic profile can emerge by decade, evidencing a (more or less) rapid socioeconomic development in relation to the evolution of forest fires in Italy.
\end{abstract}

Keywords: fire history; indicators; exploratory data analysis; Italy

\section{Introduction}

Having a long fire history, Mediterranean countries, e.g., Italy, are particularly sensitive to wildfires and respond through dedicated legislation, policies and practical measures to increasing fire exposure driven by land-use and climate changes [1-3]. Earlier studies based on the analysis of relatively short time-series data provided mixed evidence toward an overall increase in fire risk, revealing instead more complex spatio-temporal patterns differing between small, medium and large fires [4]. However, growing land vulnerability to large (and mega) fires is a common trend in both peri-urban districts with high human pressure and rural areas experiencing depopulation and land abandonment $[5,6]$.

Around the world, Mediterranean-like ecosystems are probably the most wildfire-prone areas [7-9]. In Europe, according to the Burned Areas Perimeters (BAP) dataset of the European Forest Fire Information System (EFFIS), Spain, France, Portugal, Italy and Greece account for $78 \%$ of total burnt area and $84 \%$ of the total number of fires recorded in Europe in the 2000-2013 period [7]. 
Furthermore, the spatial distribution of fire incidence (e.g. number of fires and burnt area) is not spatially homogenous among these countries or within different regions of the same country [7]. However, forest fires can derive multiple explanations, e.g., divergent socioeconomic backgrounds, in different Mediterranean countries. For instance, wildfires, frequently occurring in woodlands, are usually called "forest fires", depending on type of vegetation being burnt [10-21]. However, in regions such as the Mediterranean basin, both forested and non-forested areas result in being highly fire-prone due to climatic characteristics since fire plays a vital role in the ecosystem structure and function $[2,8,22,23]$.

Based on these premises, a dedicated statistical analysis of longer time-series of fire frequency and severity may refine knowledge of fire behavior advancing strategies containing fire risk and reducing post-fire environmental rehabilitation costs. This study investigates long-term historical patterns of forest fires in Italy (1961-2017) using a mixed approach based on time-series statistical analysis, multivariate techniques and regressive models aimed at defining changes in fire regimes vis à vis socioeconomic development. A comparative assessment of the socioeconomic aspects and wildfire trends can reveal a key step to recognizing mitigation and preventive possibilities [10,11]. Since fires often have an anthropogenic matrix and affect society and the local economy, it is unthinkable to correlate fires to these aspects [24,25]. However, the present work focuses on the temporal component. Often, time is a secondary variable, while in this work it assumes a major role given the long time series (1961-2017) that describe fires in Italy. Time assumed a key importance in this work, although fire risk assessment systems usually offer a spatial assessment of the most relevant components associated with fire occurrence. For instance, fires are constantly judged as human-caused events [26-28]. Socioeconomic development, demographic dynamics and forest fires are, therefore, analyzed based on an extended time period. Moreover, short time frames (as a temporal period used for assessing a specific event) may be satisfactory for evaluating ecosystem dynamics. However, a long time series allows this work to reflect on the long period of the history of fires and their effects in Italy. For that reason, longer time scales are relevant to understanding and managing landscapes with long-lived systems, including forests [29-32].

\section{Methodology}

\subsection{Study Area}

The investigated area covers the whole of Italy $\left(301,330 \mathrm{~km}^{2}\right.$ with rugged topography: $23 \%$ lowland, $42 \%$ upland and 35\% mountains). The country displays marked disparities in environmental conditions (climate regimes, landscape, vegetation, soils and cropping systems) and socioeconomic factors (income, job market, demographic and socio-spatial structures) between northern and southern regions [33-35]. Recent demographic trends in Italy and a complete outlook of socioeconomic characteristics at national scale were presented in earlier studies [31,36-38].

\subsection{Indicators}

Long-term forest fire trends were assessed using statistical data on the frequency and severity of fire events in Italy between 1961 and 2017 disseminated by Istat (Italian National Statistical Office) and complemented with additional information provided by Italian Forestry Service. For each year, three indicators were calculated: (i) total number of forest fires, (ii) total forest burnt area (ha) and (iii) average fire size (ha) at national level in Italy. These data were supplemented with detailed information on fire events in non-forest, natural land (pastures, cropland, wetland), available for a shorter time period (1970-2017) from Istat, allowing calculation of the following three variables: (i) total number of non-forest (wild)fires, (ii) total (non-forest) burnt area (ha), and (iii) average (wild)fire size (ha).

To illustrate territorial, demographic, socioeconomic and cultural transformations over the study period in Italy, this work adopted 58 contextual indicators (Appendix A) derived from a set of country-scale time-series annual data recently released by Istat. In line with the conceptual 
reference framework (the relationship between forest fires, demographic dynamics and socioeconomic development), indicators evaluate five relevant dimensions: (i) territory and environment (7 indicators), (ii) demography (12), (iii) education and labor market (7), (iv) economy and trade (8) and (v) agriculture (24). Indicators were collected and harmonized from multiple data sources (e.g., national census of population, population register, forest/environmental statistics, economic statistics, social statistics provided by Istat) with the aim of investigating post-war socioeconomic and environmental history of Italy. The identification of specific analysis' fields allows indicator sub-sets to be defined suitable for investigating together forest fires' dynamics and socioeconomic development.

\subsection{Data Analysis}

Based on exploratory thinking, this study evaluates a sufficiently large number of indicators, comparable over the entire study period. The indicators illustrated in Section 2.2 were analyzed using a mixed statistical framework including descriptive analysis, time-series partial auto-correlation and cross-correlation techniques, principal component analysis (PCA), cluster analysis and step-wise multiple regression models. Indicators were standardized prior to analysis.

A classical time-series analysis was run on three indicators (number of forest fires, total burnt area and average fire size) by computing a partial autocorrelation coefficient by lag, considering lags from 1 to 15 over 57 years. Correlation between the number of forest fires and total burnt area was investigated using a scatterplot and cross-correlation coefficients at lags ranging from 0 to 15 . Significance was tested at $p<0.05$ for both partial auto-correlation and cross-correlation coefficients. A specific PCA was run on a shorter time interval (1970-2017) with the aim of comparing temporal trends in forest and non-forest fires in Italy. Five indicators were analyzed together: (i) total number of fires (forest and non-forest), logarithm, hereafter 'Fir(log)'; (ii) total burnt area (forest and non-forest), logarithm, 'Bur(log)'; (iii) average fire size (forest), 'Avg(W)'; (iv) average fire size (non-forest), 'Avg(A)'; and, finally, (v) per cent share of burnt area of forests in total burnt area, 'Wood $(\%)^{\prime}$. Components with eigenvalues $>1$ were further analyzed using a biplot that illustrates together component loadings (5 indicators) and scores (48 years), allowing identification of characteristic years and the related fire's attributes.

A cluster analysis (two-way joining) was run to explore intensity of change in basic attributes of forest fires over time (using three indicators: ' $\operatorname{Fir}(\log )^{\prime}$, 'Bur(log)' and 'Avg $(\mathrm{W})$ ', in relation to socioeconomic development. This technique was run on a data matrix of forest fire's indicators calculated as a 10-year average, producing a central value separately for each of six decades (1961-1970, 1971-1980, 1981-1990, 1991-2000, 2001-2010 and 2008-2017). This value was compared with the corresponding value of 58 context indicators (see in the Appendix A) at the beginning of each time interval $(1961,1971,1981,1991,2001,2008)$. Two-way joining is a common multivariate technique analyzing complex data matrices under the assumption that both cases (time intervals) and variables (contextual indicators) will contribute simultaneously to the uncovering of meaningful latent patterns. Two-way clustering produces a graph ordering cases and variables based on similarity patterns. The graph illustrates the distribution of standardized scores (with zero-average) for each case and variable using different colors. Identification of similar (positive or negative) scores for a group of variables and cases allows definition of specific clusters. A PCA was also run on the same data matrix with the aim of classifying indicators in respect of time intervals characterized by different developmental phases in Italy. Components with eigenvalues $>1$ were extracted and a biplot illustrating together component loadings ( 6 indicators, one for each decade) and scores (61 indicators, i.e., 3 forest fires' attributes and 58 contextual indicators, see list in the Appendix A) was analyzed.

Multiple regression models were separately run to identify the most relevant predictors of three forest fire's attributes (number of forest fires, total burnt area, average fire size) taken as dependent variables. In each model, predictors were selected from a list of 58 indicators (see in the Appendix A) available each year from 1961 to 2009, by adopting a forward stepwise technique with $p<0.05$. Adjusted $R^{2}$ and Durbin-Watson tests were adopted to evaluate the goodness of fit of each model. 


\section{Results}

\subsection{Descriptive Statistics}

Forest fires were relatively scarce in Italy during the first decade investigated in this study, ranging between 1000 and 4000 events per year between 1961 and 1970 (Figure 1). The 10-year moving average illustrates a rapid increase in the number of forest fires during the 1970s. A peak in fire events was observed in the 1980s, with the maximum value recorded in 1985 (nearly 18,000 events). Fire frequency was relatively stable during the late 1980s and the early 1990s, and a moderate decline was observed since the mid-1990s. Results of a partial auto-correlation analysis on fire frequency indicate a short-term dependence pattern, with partial autocorrelation coefficients at both lag 1 and lag 3 being significant and positive (respectively $r=0.67$ and 0.36 ). In other words, fire frequency has influenced significantly the number of forest fires in the subsequent year, and more slightly, three years later. Total burnt area (forests, ha) followed a particularly volatile time pattern, increasing moderately in the 1970s, stabilizing in the 1980s, reaching a local peak in the 1990s and declining slightly in the 2000s. The largest values were observed in the early 1990s and in the late 2000s. Results of a partial auto-correlation analysis on total burnt area indicate a non-significant time-dependence pattern, reflecting high variability of this indicator over time.
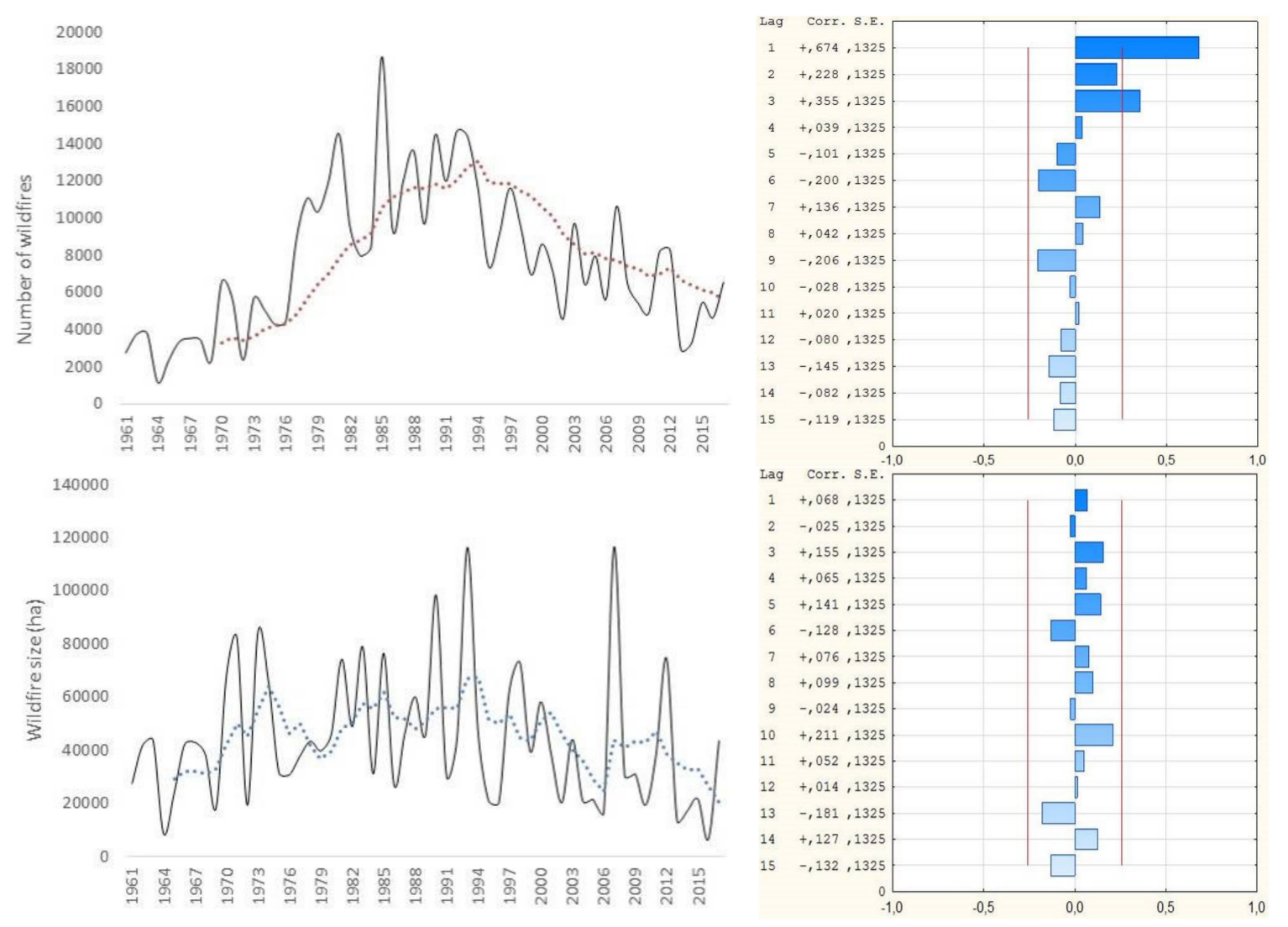

Figure 1. Cont. 

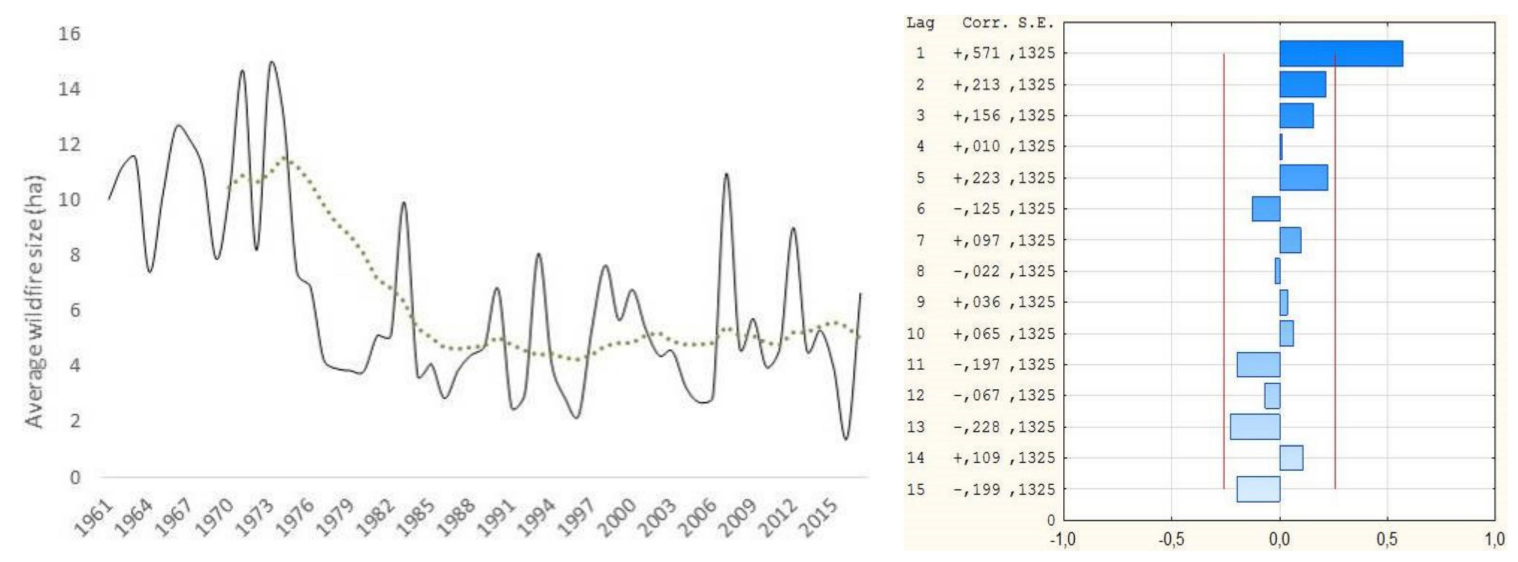

Figure 1. Selected forest fires' attributes in Italy, 1961-2017 (upper: number of wildfires; intermediate: total burnt area; lower: average wildfire size; left: absolute time series-continuous line, and 10-year moving average-dotted line; right: partial autocorrelation coefficients by lag, straight line indicates $95 \%$ confidence interval, as it increases by each lag, the colors lighten from shades of dark blue to light blue).

Average forest fire size (ha) was relatively high in the first two decades, declining since the late 1970s and stabilizing to nearly 6 ha in the following decades, while reaching peaks up to 10 ha in exceptional years (e.g., 1985, 2007). A slight increase was finally observed in the last decade. A partial auto-correlation analysis on average fire size indicates a short-term dependence pattern, with a significant, positive autocorrelation coefficient $(\mathrm{r}=0.57)$ at lag 1 . A correlation analysis was also performed between total number of forest fires and total burnt area in Italy, 1961-2017 (Figure 2). Exceptional years were classified in the upper side of the scatterplot: 1990, 1993 and 2007 had the largest forest area destroyed by fires; conversely, 1985 had the largest number of fires since 1961. Years in the early 1970s were classified in the upper part of the graph $(1970,1971,1973,1974)$. Conversely, early 1990s, 2000s and 2010s years were frequently classified in the lower part of the graph. Synchronic (lag 0) correlation between the two variables was positive and significant $(\mathrm{r}=0.60)$. Diachronic correlation patterns (for both negative and positive lags) were non-significant.
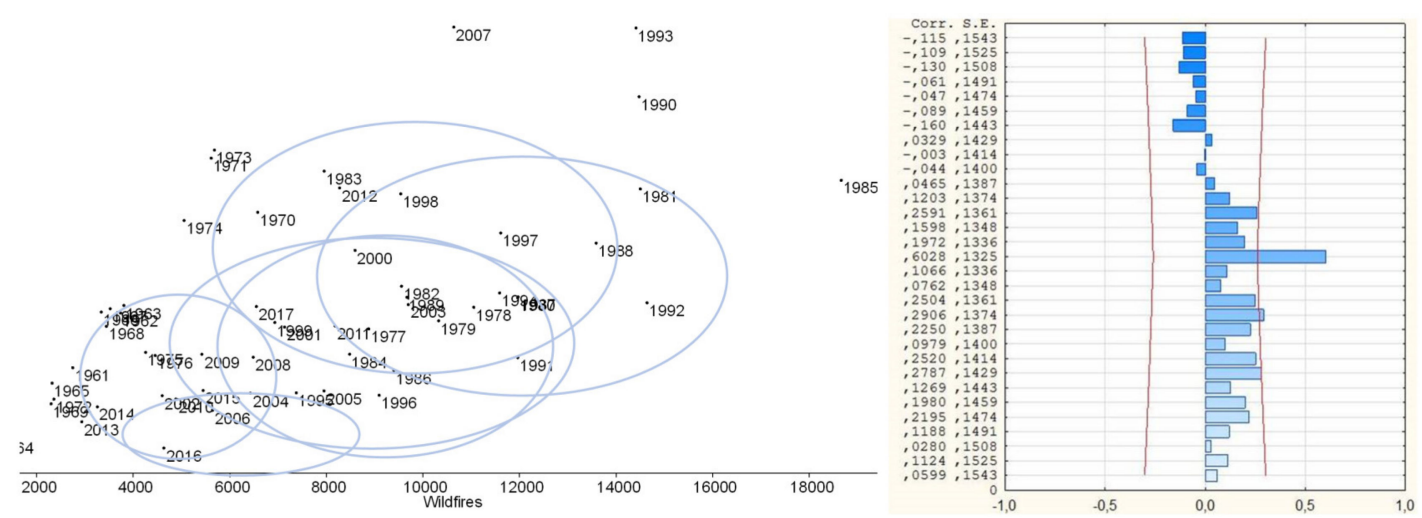

Figure 2. Correlation between the number of forest fires and total burnt area $\left(\mathrm{km}^{2}\right)$ in Italy, 1961-2017 (left) and a cross-correlation analysis of the two variables by lag (right).

Considering together forest and non-forest fires over a shorter time period (1970-2017), Principal Component Analysis extracted two axes that explain $82.4 \%$ of total variance (Figure 3). The biplot illustrating loadings and scores to components $1(47.3 \%)$ and $2(35.1 \%)$, discriminated fire attributes from fire seasons (i.e., years) within the four quadrants. Years from 1970 to 1976 were clustered together in quadrant IV (negative scores to component 1, positive scores to component 2), being associated with the per cent share of forests in total burnt area and average forest fire size (1999 and 2012 belong to this 
quadrant, even if marginally). Quadrant I include years from the 1990s and more sparse years from the 1980s, the 2000s and the 2010s. These years are associated with both total burnt area and average non-forest fire size and are considered as particularly severe years as far as the fire regime is concerned. The total number of fires was associated with component 1. Quadrant II identifies years with a relatively high fire frequency and low percentage of forest land burnt. This group is relatively mixed, including years from the 1990s, the early 2000s and the late 1970s. Quadrant III identifies years with a moderate (or low) fire severity, having together lower-than-average total burnt area and fire frequency. Together with 1995, years of the 2000s and 2010s were more frequently classified in this quadrant.

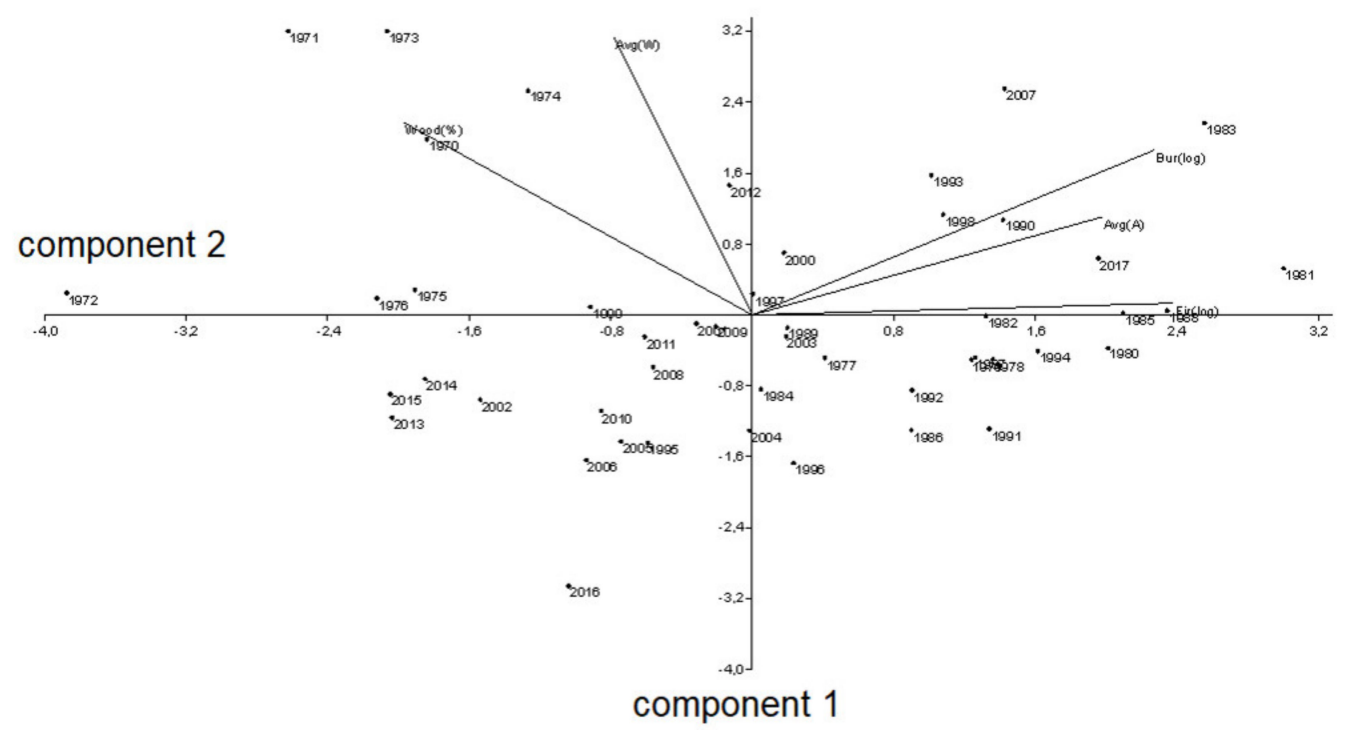

Figure 3. Principal component analysis (PCA) of basic wildfires' attributes in Italy, 1970-2017.

\subsection{Clustering and Ordination}

Two-way joining indicates a substantial difference in the socioeconomic profile of each decade (Figure 4), evidencing (more or less) rapid changes in forest fires' attributes in relation with socioeconomic development in Italy. The first two decades (1960s and 1970s) were identified with above-average demographic indicators and below-average economic and agriculture indicators. The third decade (1980s) was relatively mixed, displaying some above-average economic and labor market/education indicators. The last three decades were more similar, representing the inherent divide between agricultural indicators (above-average) and demographic indicators (below-average). Figure 4 depicted two-way joining cluster analysis by choosing a color graduation, which starts from the green tones for the lowest values below the average up to the red tones for the values above the average.

Considering forest fires and socioeconomic dynamics (1961-2017), a PCA run on the same data matrix explored by two-way joining (see above) extracted two axes that explain $75.2 \%$ of total variance (Figure 5). The biplot illustrating components $1(55.7 \%)$ and $2(19.5 \%)$ discriminated fire/socioeconomic attributes and decades within the four quadrants. The 1960s decade was negatively associated with component 1 . The most relevant fire variable associated with this decade was average fire size (reaching in this period the highest values over the whole time series, see Section 3.1) in turn linked with a group of territorial, demographic, agricultural and trade indicators. The subsequent decade was also associated with component 2 and identified a group of variables typically associated with rapid socioeconomic development (reflecting a rising production of specific agricultural products, growing imports, and increasing wealth and savings). The 1980s was a sort of transition period for socioeconomic development, being associated with component 2 and linked to specific forest fires' variables (and especially total burnt area, reaching the highest values in this decade, see Section 3.1). The last three decades were positively associated with component 1 . Years in the 1990s were weakly associated to fire frequency and more tightly associated with a group of variables indicating specific 
agricultural productions (oil, barley, eggs, wine, tobacco, hazel, livestock), population concentration, urbanization, and specific education variables. The 2000s and 2010s were found to be associated with specific variables, including demographic aspects (migration, ageing), increasing imports from Europe, high-value or niche agricultural productions, and a territorial context characterized by forest expansion thanks to land abandonment and increased environmental protection.

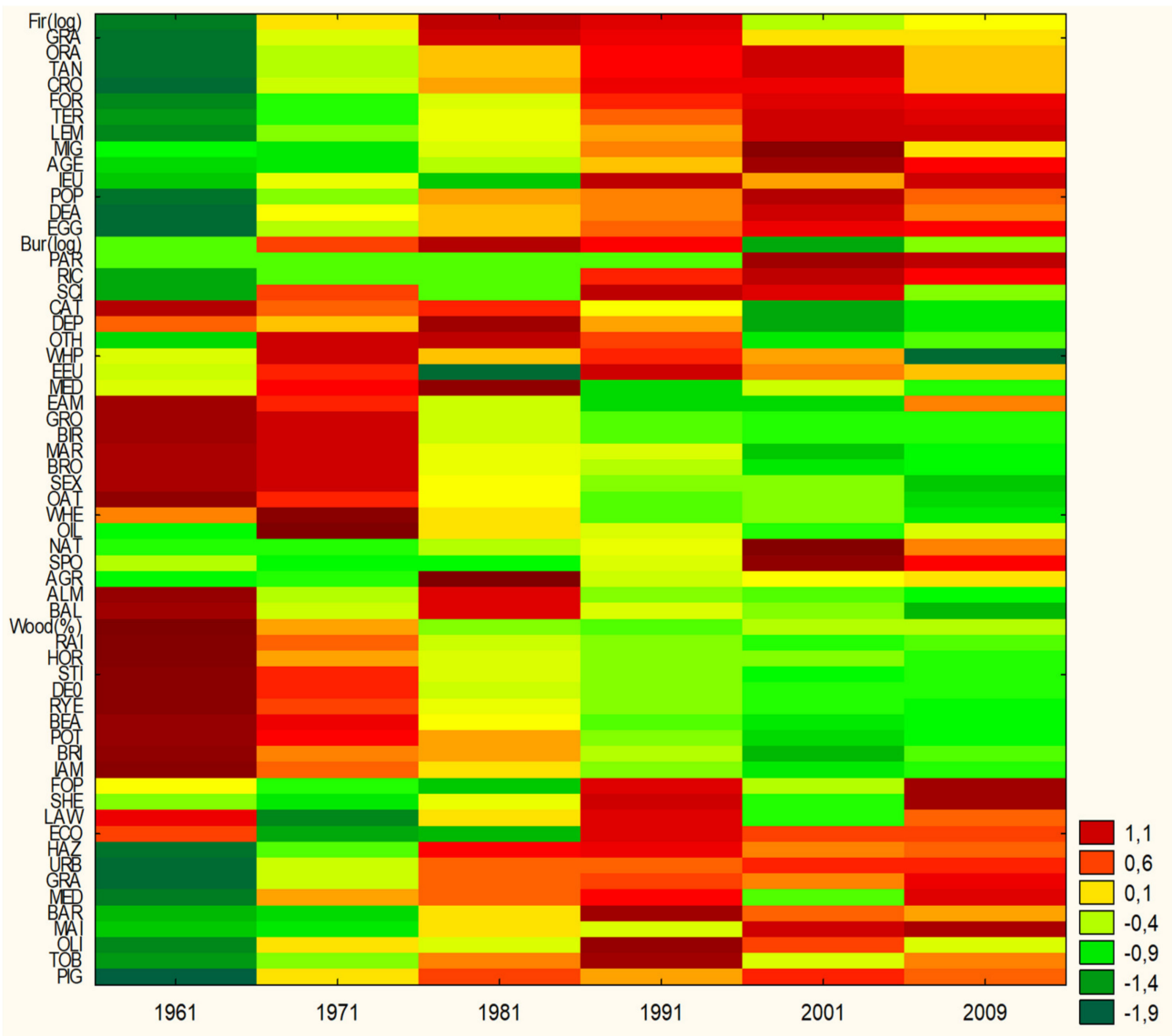

Figure 4. Two-way joining cluster analysis using color graduation from green to red, respectively indicating indicators' value below and above the average.

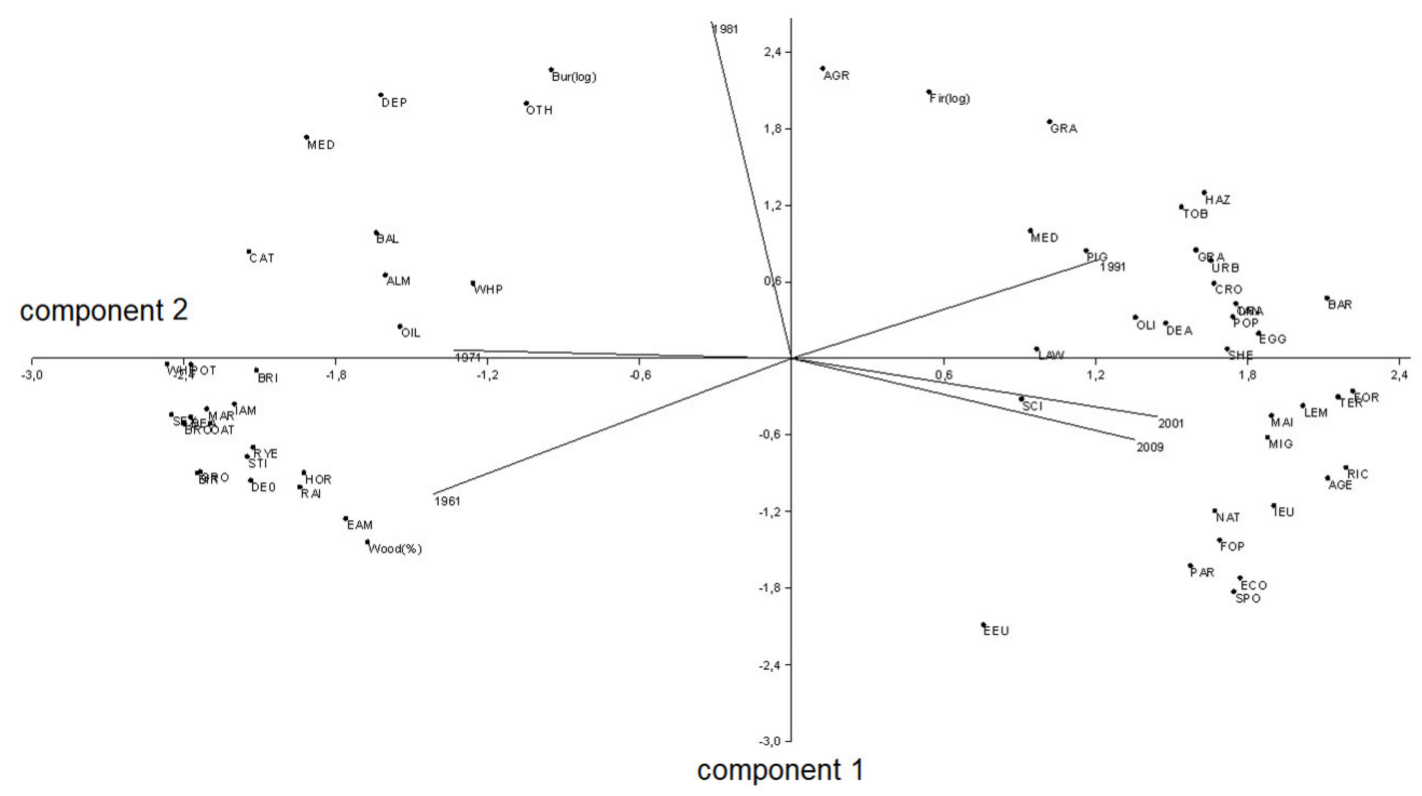

Figure 5. Principal component analysis of basic forest fires and socioeconomic attributes in Italy, 1961-2008. 


\subsection{Multiple Regression}

Step-wise multiple regressions were run with the aim of identifying the most relevant predictors of (i) forest fire frequency (ii) total burnt area (forests) and (iii) average fire size (forests). Selected forest fires' attributes assumed as dependent variables are: barley production ('BAR'), per cent share of school graduates in total population ('GRA'), other agrumes' production per 1000 quintals ('OTH'), crude birth rate as percentage on total population ('BIR'), marriage rate ('MAR') and lemon production per 1000 quintals ('LEM') (see in the Appendix A). Step-wise selection of the predictors gave relatively good models (moderate-high adjusted $\mathrm{R}^{2}$ ) for dependent variables (i) and (iii). The model for variable (ii) has a rather modest fit and it is not considered here, confirming the large variability over time of total burnt area, that could be better explained with the use of other predictors, including descriptors of climate/meteorological regimes (Table 1). The number of forest fires was positively correlated with barley production ('BAR') and per cent share of school graduates in total population ('GRA'). This model suggests that the highest fire frequency was observed in connection with a phase of rapid socioeconomic changes during the 1980s, with specific agricultural productions and a (more or less) rapid increase in education level. Conversely, average fire size was positively correlated with birth ('BIR') and marriage rate ('MAR') and with lemon production ('LEM'). These variables indicate that the highest values of fire size were observed at the beginning of the observation period, under a specific demographic context ('baby boom') and a more traditional agricultural system dominated by perennial crop.

Table 1. Results of forward step-wise multiple regression models using selected forest fires' attributes as dependent variables.

\begin{tabular}{cccccccccc}
\hline \multirow{2}{*}{ Predictor } & \multicolumn{3}{c}{ Number of Forest Fires } & \multicolumn{3}{c}{ Burnt Area } & \multicolumn{3}{c}{ Average Fire Size } \\
\cline { 2 - 10 } & $\mathbf{b}$ & $\mathbf{S E}$ & $\mathbf{t}$ & $\mathbf{b}$ & $\mathrm{SE}$ & $\mathbf{t}$ & $\mathbf{b}$ & SE & $\mathbf{t}$ \\
\hline BAR & 0.462 & 0.11 & $4.2^{* *}$ & & & & & & \\
GRA & 0.460 & 0.11 & $4.2^{* *}$ & & & & & & \\
OTH & & & & 0.313 & 0.14 & $2.26^{*}$ & & & \\
MAR & & & & & & & 0.893 & 0.35 & $2.58^{*}$ \\
BIR & & & & & & & 0.503 & 0.27 & $3.88^{*}$ \\
LEM & & & & & & & 0.748 & 0.19 & $1.83^{*}$ \\
Adj-R & & 0.716 & & & 0.079 & & & 0.636 & \\
D-W test & & 2.11 & & & 2.11 & & & 1.91 & \\
\hline
\end{tabular}

b: standard slope; SE: standard error; Student t statistic testing for non-null regression coefficients at * $p<0.05$ or ${ }^{* *} p<0.001$; D-W: Durbin-Watson test of serial autocorrelation, values close to 2 indicate negligible autocorrelation.

\section{Discussion}

The occurrence and severity of forest fires in each area are fundamental variables when exploring long-term fire dynamics, producing a basic knowledge to evaluate the effectiveness of fire management systems at local, regional and national level [7,22,39]. Understanding past and present fire regimes is, in turn, essential to determining the extent and seasonality of fires, ignition cause and fire behavior [4,40-44]. Earlier studies using a long time-series analysis have demonstrated that fire regimes have shaped landscapes as a function of both climate and human feedbacks [7-11,40-42]. Changes in fire regimes have determined considerable pressures to natural ecosystems and human settlements [45], since fires have frequently led to (more or less) rapid landscape transformations [46]. Comparative investigations of fire history have outlined a high occurrence of fires during the mid to late 19th century [47-49]. Fire regimes occurred between the late 20th and the early 21st centuries were characterized by more volatile climatic and vegetation conditions $[1,49,50]$.

The recurrence of fires turns out to be frequent in recent years, varying meaningfully the current fire regimes. A fire regime can be characterized by the pattern, frequency and intensity of the fires that occurred in a definite area over long temporal phase [40,41]. Fire regime analysis is 
particularly interesting for disentangling the role played by anthropogenic pressure on severity and fire frequency [50-57]. Fire severity defines the eco-systemic influence of a fire, e.g., as biomass damage to fire; while, fire frequency outlines the number of fires in a specific place and during a defined temporal period, differing by region as a meaning of both lightning and anthropologic ignitions, with the prerequisite that fuels are adequately dry and significantly combustible to burn [46].

Wildfires seem to be a considerable threat to human and ecological values in the fire-prone areas of the Mediterranean basin, where extreme fire periods are frequent causing human and ecological losses $[1,7,10,11,21,58]$. In recent years (2000-2009), Italy with other Mediterranean countries in Europe (France, Spain, Greece) experienced about 57,000 wildfires yearly, burning 430,000 ha [1,10,11,59]. More than $90 \%$ of fires were produced by negligence, pyromania and agro-pastoral land burning [10]. Wildfires characterized a current concern since it is expected that they will increase in reply to foreseen changes in climate and land-use in the future [60,61].

The latent interplay between socioeconomic development and environmental conditions has been frequently investigated in multifaceted research fields dealing with climate change, land-use, soil degradation and other issues involving global, regional and local spatial scales [62-69]. Being difficult to predict [70], forest fires represent a relevant ecological process in Mediterranean Europe [40,41]. Empirical research on forest fires in southern Europe has increased rapidly since the 1970s [39,71]. Despite mostly volatile and heterogeneous short-term regimes, a comprehensive understanding of forest fires' behavior requires diachronic analysis of multiple fire attributes over enough long temporal scales [72]. In this context, fire history became a specific issue of study, considering territorial specificities and intensifying burning perspectives as a multi-purpose tool [9,73]. Furthermore, especially in Mediterranean Europe, fire history can be easily correlated with anthropogenic activities, which have developed traditional (or advanced) agricultural practices and have directly or indirectly shaped landscapes and land cover [2,74]. For instance, recent trends in landscape transformation [3,49,75-78], models of economic development and lifestyles have directed towards new territorial scenarios for wildfire ignition $[9,79]$. In addition, climate change and degradation processes (e.g., soil erosion and desertification) have increased the interest on regional vulnerability to wildfires [59-62,80-84].

The present work outlined the importance of exploring long time-series of forest fire attributes together with a wide-ranging set of socioeconomic indicators. Empirical results outlined significant changes in both frequency and severity of forest fires in Italy. Forest fires were relatively scarce in Italy during the first decade investigated (1961-1970). Subsequently, a rapid increase in the number of forest fires occurred during the 1970s, with a peak in fire events in the 1980s, with the maximum value recorded in 1985. Fire frequency was relatively stable during the late 1980s and the early 1990s, declining since the mid-1990s. Results exposed the fact that fire frequency influenced significantly the number of forest fires in the subsequent year, and more slightly, three years later. Correlation between fire frequency (absolute number of events) and fire severity (total burnt area) identifies fire seasons with a characteristic risk profile, having e.g., above-average fire frequency and severity. Among the main indicators, total burnt area followed a predominantly unpredictable time pattern, (i) increasing moderately in the 1970s, (ii) calming in the 1980s, (iii) reaching a local peak in the 1990s, and (iv) decreasing slightly in the 2000s. Outcomes of a partial auto-correlation analysis on total burnt area exposed a non-significant time-dependence outline, reflecting high variability of such an indicator over time. Fire's behavior over single years evidenced 'risky' characteristics, possibly linked with specific environmental conditions (climate, vegetation, landscape) [83,84]. At the same time, a more general trend over time was observed for all fire's attributes, evidencing different behaviors and background patterns: fire frequency increased up to the mid-1980s and decreased slightly afterwards, and total burnt area was even more volatile. Within this framework, time-series analysis indicates a partial autocorrelation structure characterized by a significant lag-1 positive autocorrelation, suggesting that both fire frequency and average fire size are positively influenced by the level of the same variable one year before. Socioeconomic development was also an important factor explaining the temporal pattern 
of forest fires $[27,85,86]$. In particular, demographic and productive aspects were associated with fire's attributes over time, confirming the key role of human pressure (caused by multiple factors, including e.g., an increase in population density or changes in agricultural productions) in fire risk [42,84,87-92]. For instance, the increasing gap between marginal and highly populated areas is an important aspect leading to a larger unpredictability of fire events. In this regard, areas with more evident processes of land abandonment seem to be more vulnerable to large fires, while fires are smaller and more frequent in peri-urban districts because of high anthropogenic pressure [85,93-98].

Also, the average forest fire size is a significantly indicator since it was comparatively high in the first two decades, declining since the late 1970s and stabilizing to nearly 6 ha in the succeeding decades, while reaching peaks up to 10 ha in extraordinary years (e.g., 1985, 2007). Considering together forest and non-forest fires over a shorter time period (1970-2017), principal component analysis discriminated fire attributes from fire seasons (i.e., years), e.g., years from the 1990s and more sparse years from the 1980s, the 2000s and the 2010s. These years are associated with both total burnt area and average non-forest fire size and are considered as predominantly severe years as far as the fire regime is concerned.

While socioeconomic development is demonstrated to be strongly associated with fire's attributes, mainly frequency and average size, other factors cannot be demised when understanding complex trends in fire risk. The present analysis contributes to shed light on long-term fire risk trends in a Mediterranean country. Proposing a truly comprehensive approach to fire's complexity [23], the originality of this paper is in bringing out and indicating in each decade a considerable change in the socioeconomic profile, demonstrating variations in forest fires' attributes in relation to socioeconomic development in Italy: (i) the first two decades (1960s and 1970s) were recognized as having above-average demographic indicators and below-average economic and farming indicators; (ii) the third decade (1980s) was relatively mixed, exhibiting some above-average economic and labor market/education indicators; and (iii) the last three decades were more similar, on behalf of the inherent division among agricultural indicators (above-average) and demographic indicators (below-average). Furthermore, the recent decades (2000 and 2010) were found to be related to explicit variables, counting demographic aspects (e.g., migration), growing imports from Europe, high-value or niche agricultural production, and a territorial context composed by forest expansion due to land abandonment and improved environmental protection. Analysis of long time-series of fire events unquestionably allows the identification of wildfire scenarios, which represent an indirect approach to accomplishing fire hazard reduction and land management, evaluating together fire events and human-driven activities $[39,45]$.

An integrative concept, including bio-geophysical processes and social structures, can provide a large-scale standpoint appropriate for managing ecosystems and human activities [9,45,47-51]. Although it is a multivariate analysis, a substantial difference in the socioeconomic profile can emerge by decade, evidencing a (more or less) rapid socioeconomic development in relation with the evolution of forest fires in Italy. In this sense, the work proposed allows us to reflect also on recent environmental challenges, e.g., climate regimes which should be better investigated in this line of thinking [1]. Innovative approaches for the integrated management of wildland under changing socioeconomic conditions contributes to a better knowledge of the spatio-temporal dynamics of wildfires in prone areas, suggesting new fire scenarios [102]. In this instance, fire scenarios are useful when they are based both on (i) a location-based approach, referring to the dynamic connotation among fire behavior, ecological issues, socioeconomic aspects and land-use management at a landscape scale [99], and (ii) a time-based approach, which simulates single events regarding alternative temporal pathways for upcoming forecasts of fire risk $[100,101]$. Thanks to new technologies, multi-temporal databases should be permanently updated and enriched with the final objective of depicting fire history and changing fire regimes in each area [102-107]. Renewed strategies of fire prevention and forecast should be increasingly based on a multi-criteria approach that includes advanced knowledge of a time-series joint analysis of wildfires and socioeconomic development. 


\section{Conclusions}

Despite Mediterranean countries being strongly sensitive to fire risk, few researches have focused on long-term fire risk trends, especially related to socioeconomic development. The present study offers an integrated time-series analysis along a long temporal series (1961-2017) exploring forest fires in Italy and the relative socioeconomic and demographic dynamics. Among the numerous indicators, number of fire events, total burnt area and average fire size were studied with the aim of identifying homogeneous time periods with similar wildfire frequency and severity and correlating them with the background socioeconomic context. Investigating trends of forest fires over the last decades, a mixed approach was based on time-series statistical analysis, multivariate techniques and regressive models, proposed at defining variations in fire regimes and socioeconomic development. The comparative assessment of the socioeconomic aspects and wildfire trends revealed a key step to identifying mitigation and preventive possibilities. As regards current concerns, e.g., climate changes and regimes, a truly comprehensive approach to fire's complexity is necessary [47], offering wildfire scenarios, which embody an ancillary approach to achieving fire hazard reduction and land management, assessing both fire events and human-driven activities [39]. The present work focused on temporal data, without defining a precise place definable in space: the lack of spatial linkage among fire occurrence points, regions and descriptive information is a weakness, which could be filled by future studies. However, a substantial difference in the socioeconomic profile can arise by decade, proving a (more or less) rapid socioeconomic change in relation with the development of forest fires in Italy. An integrative approach can offer a large-scale perspective, which can be very appropriate for managing the future of fragile ecosystems and human activities [9,32].

Author Contributions: Conceptualization, A.C. and M.C.; methodology, L.S.; software, I.Z.; validation, I.Z; formal analysis, L.S.; investigation, M.C.; resources, M.C.; data curation, A.C.; writing—original draft preparation, L.S.; writing-review and editing, L.S., M.C.; visualization, I.Z.; supervision, A.C.; funding acquisition, L.S.

Funding: This research was funded by two projects: SMART4Action (grant no. LIFE13 ENV/IT/000813) financed by European Union and CRISIS, a Sapienza University grant to M.C.

Conflicts of Interest: The authors declare no conflict of interest.

\section{Appendix A}

Table A1. Indicators adopted in the present study by thematic domain.

\begin{tabular}{|c|c|c|c|}
\hline Theme & Acronym & Indicator & Source \\
\hline \multirow{7}{*}{ Territory } & FOR & Forest land (\% in total land) & Forest statistics \\
\hline & FOP & Per-capita forest area ( $\mathrm{m}^{2}$ per inhabitant) & Forest statistics \\
\hline & GRO & Population growth rate (\% per year) & Demographic statistics \\
\hline & POP & Resident population (logarithm) & Demographic statistics \\
\hline & PAR & Protected area (\% in total land) & Environmental statistics \\
\hline & RAI & Railway network (km/1000 inhabitants) & Economic statistics \\
\hline & URB & Population residing in urban centers (\% in total popul.) & Demographic statistics \\
\hline \multirow{12}{*}{ Demography } & SEX & Sex ratio (males vs females) & Demographic statistics \\
\hline & BIR & Crude birth rate (\% in total population) & Demographic statistics \\
\hline & DEA & Crude death rate (\% in total population) & Demographic statistics \\
\hline & MIG & Migration rate (\% in total population) & Demographic statistics \\
\hline & NAT & Natural birth rate (\% in total births) & Demographic statistics \\
\hline & STI & Still birth rate (\% in total births) & Demographic statistics \\
\hline & BRI & Age difference between groom and bride (years) & Demographic statistics \\
\hline & MAR & Marriage rate ( $\%$ in total population) & Demographic statistics \\
\hline & $\mathrm{SPO}$ & Average age of the groom at the marriage (years) & Demographic statistics \\
\hline & AGE & Median age at death for males (years) & Demographic statistics \\
\hline & MER & Difference in female vs male median age (years) & Demographic statistics \\
\hline & DE0 & Death at age $0-4$ years (\% in total population) & Demographic statistics \\
\hline
\end{tabular}


Table A1. Cont.

\begin{tabular}{|c|c|c|c|}
\hline Theme & Acronym & Indicator & Source \\
\hline \multirow{7}{*}{ Education } & TER & Third-level graduated (\% in total population) & University statistics \\
\hline & GRA & Second-level graduated (\% in total population) & School statistics \\
\hline & SCI & Enrolled at the university in science faculties (\%) & University statistics \\
\hline & MED & Enrolled at the university in medicine faculties (\%) & University statistics \\
\hline & AGR & Enrolled at the university in agrarian faculties (\%) & University statistics \\
\hline & ECO & Enrolled at the university in economy faculties (\%) & University statistics \\
\hline & LAW & Enrolled at the university in law faculties (\%) & University statistics \\
\hline \multirow{24}{*}{ Agriculture } & WHP & Wheat production (per 1000 quintals) & Agricultural statistics \\
\hline & RYE & Rye production (per 1000 quintals) & Agricultural statistics \\
\hline & BAR & Barley production (per 1000 quintals) & Agricultural statistics \\
\hline & OAT & Oat production (per 1000 quintals) & Agricultural statistics \\
\hline & RIC & Rice production (per 1000 quintals) & Agricultural statistics \\
\hline & MAI & Maize production (per 1000 quintals) & Agricultural statistics \\
\hline & $\mathrm{BRO}$ & Broad bean production (per 1000 quintals) & Agricultural statistics \\
\hline & BEA & Bean production (per 1000 quintals) & Agricultural statistics \\
\hline & POT & Potatoes production (per 1000 quintals) & Agricultural statistics \\
\hline & TOB & Tobacco production (per 1000 quintals) & Agricultural statistics \\
\hline & GRA & Wine grapes production (per 1000 quintals) & Agricultural statistics \\
\hline & OLI & Olive production (per 1000 quintals) & Agricultural statistics \\
\hline & ORA & Orange production (per 1000 quintals) & Agricultural statistics \\
\hline & TAN & Tangerine and clementine production (per 1000 quintals) & Agricultural statistics \\
\hline & LEM & Lemon production (per 1000 quintals) & Agricultural statistics \\
\hline & $\mathrm{OTH}$ & Other agrumes' production (per 1000 quintals) & Agricultural statistics \\
\hline & ALM & Almond production (per 1000 quintals) & Agricultural statistics \\
\hline & HAZ & Hazel production (per 1000 quintals) & Agricultural statistics \\
\hline & $\mathrm{CRO}$ & Per capita agricultural production (quintals) & Agricultural statistics \\
\hline & CAT & Total density of cattle and buffaloes (animals) & Agricultural statistics \\
\hline & SHE & Total density of sheep and goats (animals) & Agricultural statistics \\
\hline & PIG & Total density of pigs (animals) & Agricultural statistics \\
\hline & HOR & Total density of horses (animals) & Agricultural statistics \\
\hline & EGG & Total number of eggs produced (per 1000 units) & Agricultural statistics \\
\hline \multirow{8}{*}{ Economy } & IEU & Imports from Europe (\% in total import) & Trade statistics \\
\hline & IAM & Imports from north America (\% in total import) & Trade statistics \\
\hline & EEU & Exports to Europe (\% in total import) & Trade statistics \\
\hline & EAM & Exports to north America (\% in total export) & Trade statistics \\
\hline & DEP & Bank deposit amount/total loan amount & Economic statistics \\
\hline & OIL & Imported oil/imported carbon & Trade statistics \\
\hline & WHE & Wheat production/wheat import & National accounts \\
\hline & BAL & Total import/total export & Trade statistics \\
\hline
\end{tabular}

\section{References}

1. Lozano, O.M.; Salis, M.; Ager, A.A.; Arca, B.; Alcasena, F.J.; Monteiro, A.T.; Finney, M.A.; Del Giudice, L.; Scoccimarro, E.; Spano, D. Assessing climate change impacts on wildfire exposure in Mediterranean areas. Risk Anal. 2017, 37, 1898-1916. [CrossRef] [PubMed]

2. Galiana-Martin, L.; Herrero, G.; Solana, J. A wildland-urban interface typology for forest fire risk management in Mediterranean areas. Landsc. Res. 2011, 36, 151-171. [CrossRef]

3. Viedma, O.; Moity, N.; Moreno, J.M. Changes in landscape fire-hazard during the second half of the $20^{\text {th }}$ century: Agriculture abandonment and the changing role of driving factors. Agric. Ecosyst. Env. 2015, 217, 126-140. [CrossRef]

4. Morgan, P.; Hardy, C.C.; Swetnam, T.W.; Rollins, M.G.; Long, D.G. Mapping fire regimes across time and space: Understanding coarse and fine-scale fire patterns. Int. J. Wildland Fire 2001, 10, 329-342. [CrossRef]

5. Cutter, S.L.; Boruff, B.J.; Shirley, W.L. Social vulnerability to environmental hazards. Soc. Sci. Q. 2003, 84, 242-261.

6. Cutter, S.L.; Finch, S. Temporal and spatial changes in social vulnerability to natural hazards. Proc. Natl. Acad. Sci. USA 2009, 105, 2301-2306. [CrossRef] [PubMed]

7. Pereira, M.G.; Malamud, B.D.; Trigo, R.M.; Alves, P.I. The history and characteristics of the 1980-2005 Portuguese rural fire database. Nat. Hazards Earth Syst. Sci. 2011, 11, 3343-3358. [CrossRef] 
8. Spies, T.A.; White, E.M.; Kline, J.D.; Fischer, A.P.; Ager, A.A.; Bailey, J.; Bolte, J.; Koch, J.; Platt, E.; Olsen, C.S.; et al. Examining fire-prone forest landscapes as coupled human and natural systems. Ecol. Soc. 2014, 19, 9. [CrossRef]

9. Montiel-Molina, C. Comparative assessment of wildland fire legislation and policies in the European Union: Towards a Fire Framework Directive. For. Policy Econ. 2013, 29, 1-6. [CrossRef]

10. Ager, A.A.; Kline, J.; Fischer, A.P. Coupling the biophysical and social dimensions of wildfire risk to improve wildfire mitigation planning. Risk Anal. 2015, 35, 1393-1406. [CrossRef] [PubMed]

11. Ager, A.A.; Preisler, H.K.; Arca, B.; Spano, D.; Salis, M. Wildfire risk estimation in the Mediterranean area. Environmetrics 2014, 25, 384-396.

12. Fischer, A.P.; Spies, T.A.; Steelman, T.A.; Moseley, C.; Johnson, B.R.; Bailey, J.D.; Ager, A.A.; Bourgeron, P.; Charnley, S.; Collins, B.M.; et al. Wildfire risk as a socioecological pathology. Front. Ecol. Environ. 2016, 14, 276-284. [CrossRef]

13. Nielsen-Pincus, M.; Ribe, R.G.; Johnson, B.R. Spatially and socially segmenting private landowner motivations, properties, and management: A typology for the wildland urban interface. Landsc. Urban Plan. 2015, 137, 1-12. [CrossRef]

14. Oliveira, S.; Zêzere, J.L.; Queirós, M.; Pereira, J.M. Assessing the social context of wildfire-affected areas. The case of mainland Portugal. Appl. Geogr. 2017, 88, 104-117. [CrossRef]

15. Olsen, C.S.; Kline, J.D.; Ager, A.A.; Olsen, K.A.; Short, K.C. Examining the influence of biophysical conditions on wildland-urban interface homeowners' wildfire risk mitigation activities in fire-prone landscapes. Ecol. Soc. 2017, 21. [CrossRef]

16. Paveglio, T.; Moseley, C.; Carroll, M.S.; Williams, D.R.; Davis, E.J.; Fischer, A.P. Categorizing the social context of the wildland urban interface: Adaptive capacity for wildfire and community "archetypes". For. Sci. 2015, 61, 298-310. [CrossRef]

17. Paveglio, T.B.; Edgeley, C.M.; Stasiewicz, A.M. Assessing influences on social vulnerability to wildfire using surveys, spatial data and wildfire simulations. J. Environ. Manag. 2018, 213, 425-439. [CrossRef] [PubMed]

18. Paveglio, T.B.; Nielsen-Pincus, M.; Abrams, J.; Moseley, C. Advancing characterization of social diversity in the wildland-urban interface: An indicator approach for wildfire management. Landsc. Urban Plan. 2017, 160, 115-126. [CrossRef]

19. Paveglio, T.B.; Prato, T.; Edgeley, C.; Nalle, D. Evaluating the characteristics of social vulnerability to wildfire: Demographics, perceptions, and parcel characteristics. Environ.Manag. 2016, 58, 534-548. [CrossRef] [PubMed]

20. Wigtil, G.; Hammer, R.B.; Kline, J.D.; Mockrin, M.H.; Stewart, S.I.; Roper, D.; Radeloff, V.C. Places where wildfire potential and social vulnerability coincide in the coterminous United States. Int. J. Wildland Fire 2016, 25, 896-908. [CrossRef]

21. Tedim, F.; Xanthopoulos, G.; Leone, V. Forest fires in Europe: Facts and challenges. Wildfire Hazards Risks Disasters 2015, 77-99. [CrossRef]

22. Leys, B.; Finsinger, W.; Carcaillet, C. Historical range of fire frequency is not the Achilles' heel of the Corsican black pine ecosystem. J. Ecol. 2014, 102, 381-395. [CrossRef]

23. Flannigan, M.D.; Stocks, B.J.; Wotton, B.M. Climate change and forest fires. Sci. Total Environ. 2000, 262, 221-229. [CrossRef]

24. Romero-Calcerrada, R.; Barrio-Parra, F.; Millington, J.D.A.; Novillo, C.J. Spatial modelling of socioeconomic data to understand patterns of human-caused wildfire ignition risk in the SW of Madrid (central Spain). Ecol. Model. 2010, 221, 34-45. [CrossRef]

25. Rodrigues, M.; Jiménez, A.; de la Riva, J. Analysis of recent spatial-temporal evolution of human driving factors of wildfires in Spain. Nat. Hazards 2016, 84, 2049-2070. [CrossRef]

26. Rodrigues, M.; De la Riva, J.; Fotheringham, S. Modeling the spatial variation of the explanatory factors of human-caused wildfires in Spain using geographically weighted logistic regression. Appl. Geogr. 2014, 48, 52-63. [CrossRef]

27. Román, M.V.; Azqueta, D.; Rodrígues, M. Methodological approach to assess the socio-economic vulnerability to wildfires in Spain. For. Ecol. Manag. 2013, 294, 158-165. [CrossRef]

28. Fardusi, M.J.; Chianucci, F.; Barbati, A. Concept to practice of geospatial-information tools to assist forest management and planning under precision forestry framework: A review. Ann. Silvic. Res. 2017, 41, 3-14. 
29. Ferrara, A.; Kelly, C.; Wilson, G.; Nolè, A.; Mancino, G.; Bajocco, S.; Salvati, L. Shaping the role of 'fast' and 'slow' drivers of change in forest-shrubland socio-ecological systems. J. Environ. Manag. 2016, 169, 155-166. [CrossRef] [PubMed]

30. Manetti, M.C.; Amorini, E.; Becagli, C.; Pelleri, F.; Fratini, R.; Marone, E. Enhancing chestnut coppices: Silvicultural management and socio-economic context. Ann. Silvic. Res. 2010, 36, 97-108.

31. Zitti, M.; Ferrara, C.; Perini, L.; Carlucci, M.; Salvati, L. Long-term Urban Growth and Land-use Efficiency in Southern Europe: Implications for Sustainable Land Management. Sustainability 2015, 7, 3359-3385. [CrossRef]

32. Parisien, M.-A.; Miller, C.; Parks, S.A.; DeLancey, E.R.; Robinne, F.-N.; Flannigan, M.D. The spatially varying influence of humans on fire probability in North America. Environ. Res. Lett. 2016, 11, 075005. [CrossRef]

33. Caldwell, J.C. Demographic Transition Theory; Springer: Berlin, Germany, 2006.

34. Dudley, K. The Demographic Transition. Popul. Stud. 1996, 50, 361-387.

35. Lesthaeghe, R.J.; Neidert, L. The second demographic transition in the United States: Exception or textbook example? Popul. Dev. Rev. 2006, 32, 669-698. [CrossRef]

36. Billari, F.C.; Kohler, H.P.; Andersson, G.; Lundström, H. Approaching the limit: Long-term trends in late and very late fertility. Popul. Dev. Rev. 2007, 33, 149-170. [CrossRef]

37. Caltabiano, M.; Castiglioni, M.; Rosina, A. Lowest-low fertility: Signs of a recovery in Italy? Demogr. Res. 2009, 21, 681-718. [CrossRef]

38. Salvati, L.; Carlucci, M. A Composite Index of Sustainable Development at the Local Scale: Italy as a Case Study. Ecol. Indic. 2014, 43, 162-171. [CrossRef]

39. Pausas, J.; Keeley, J.E. A burning story: The role of fire in the history of life. BioScience 2009, 59, 593-601. [CrossRef]

40. Bradstock, R.A.; Williams, J.E.; Gill, M.A. Flammable Australia: The Fire Regimes and Biodiversity of a Continent; Cambridge University Press: Cambridge, UK, 2002.

41. Heyerdahl, E.K.; Brubaker, L.B.; Agee, J.K. Spatial controls of historical fire regimes: A multiscale example from the interior west, USA. Ecology 2011, 82, 660-678. [CrossRef]

42. Cazzola, A.; Pasquini, L.; Angeli, A. The relationship between unemployment and fertility in Italy: A time-series analysis. Demogr. Res. 2016, 34, 1-38. [CrossRef]

43. Gil-Romera, G.; Carrión, J.S.; Pausas, J.G.; Sevilla-Callejo, M.; Lamb, H.F. Holocene fire activity and vegetation response in South-Eastern Iberia. Quat. Sci. Rev. 2010, 29, 1082-1092. [CrossRef]

44. López-Sáez, J.A.; Vargas, G.; Ruiz-Fernández, J.; Blarquez, O.; Alba-Sánchez, F.; Oliva, M.; Pérez-Díaz, S.; Robles-López, S.; Abel-Schaad, D. Paleofire dynamics in Central Spain during the late Holocene: The role of climatic and anthropogenic Forcing. Land. Degrad. Dev. 2011. [CrossRef]

45. Montiel Molina, C.; Galiana-Martín, L. Fire scenarios in Spain: A territorial approach to proactive fire management in the context of global change. Forests 2016, 7, 273. [CrossRef]

46. Meyfroidt, P.; Lambin, E.F. Global Forest Transition: Prospects for an End to Deforestation. Annu. Rev. Environ. Resour. 2011, 36, 343-371. [CrossRef]

47. Christopoulou, A.; Fulé, P.Z.; Andriopoulos, P.; Sarris, D.; Arianoutsou, M. Dendrochronology-based fire history of Pinus nigra forests in Mt Taygetos, Southern Greece. For. Ecol. Manag. 2013, 293, 132-139. [CrossRef]

48. Sarris, D.; Christopoulou, A.; Angelonidi, E.; Koutsias, N.; Fulé, P.Z.; Arianoutsou, M. Increasing extremes of heat and drought associated with recent severe wildfires in southern Greece. Reg. Envrion. Chang. 2014, 14, 1257-1268. [CrossRef]

49. Touchan, R.; Baisan, C.; Mitsopoulos, I.D.; Dimitrakopoulos, A.P. Fire history in European black pine (Pinus nigra Arn.) forests of the Valia Kalda, Pinus mountains, Greece. Tree-Ring Res. 2012, 68, 45-50. [CrossRef]

50. Barbier, E.B.; Burgess, J.C.; Grainger, A. The forest transition: Towards a more comprehensive theoretical framework. Land Use Policy 2009, 27, 98-107. [CrossRef]

51. Cervera, T.; Pino, J.; Marull, J.; Padró, R.; Tello, E. Understanding the long-term dynamics of forest transition: From deforestation to afforestation in a Mediterranean landscape (Catalonia, 1868-2005). 2016, in press. [CrossRef]

52. Mather, A.S. The forest transition. Area 1992, 24, 367-379.

53. Mather, A.S.; Needle, C.; Coull, J. From resource crisis to sustainability: The forest transition in Denmark. Int. J. Sustain. Dev. World Ecol. 1998, 5, 183-192. [CrossRef] 
54. Pagnutti, C.; Bauch, C.T.; Anand, M. Outlook on a Worldwide Forest Transition. PLoS ONE 2013, 8, e75890. [CrossRef] [PubMed]

55. Redo, D.J.; Graub, H.R.; Aidea, T.M.; Clark, M.L. Asymmetric forest transition driven by the interaction of socio-economic development and environmental heterogeneity in Central America. Proc. Natl. Acad. Sci. USA 2012, 109, 8839-8844. [CrossRef] [PubMed]

56. Singh, M.P. Forest transition and socio-economic development in India and their implications for forest transition theory. For. Policy Econ. 2015, 76, 65-71. [CrossRef]

57. Yackulic, C.B.; Fagan, M.; Jain, M.; Jina, A.; Lim, Y.; Marlier, M.; Muscarella, R.; Adame, P.; DeFries, R.; Uriarte, M. Biophysical and socio-economic factors associated with forest transitions at multiple spatial and temporal scales. Ecol. Soc. 2011, 16, 1-22. [CrossRef]

58. Moreira, F.; Viedma, O.; Arianoutsou, M.; Curt, T.; Koutsias, N.; Rigolot, E.; Barbati, A.; Corona, P.; Vaz, P.; Xanthopoulous, G.; et al. Landscape-Wildfire interactions in southern Europe: Implications for landscape management. J. Environ. Manag. 2011, 92, 2389-2402. [CrossRef] [PubMed]

59. JRC-IES. Forest Fires in Europe; Scientific and Technical Research Series, ISSN 1018-5593; Office for Official Publications of the European Communities: Luxembourg, 2010.

60. Arca, B.; Pellizzaro, G.; Duce, P.; Salis, M.; Bacciu, V.; Spano, D.; Ager, AA.; Finney, MA. Climate Change Impact on Fire Probability and Severity in Mediterranean Areas; Viegas, D., Ed.; VI International Conference on Forest Fire Research. 9; University of Coimbra: Coimbra, Portugal, 2010.

61. Moriondo, M.; Good, P.; Durao, R.; Bindi, M.; Giannakopoulos, C.; Corte-Real, J. Potential impact of climate change on fire risk in the Mediterranean area. Clim. Res. 2006, 31, 85-95. [CrossRef]

62. Ceccarelli, T.; Bajocco, S.; Perini, L.; Salvati, L. Urbanisation and Land Take of High-Quality Agricultural Soils-Exploring Long-term Land Use Changes and Land Capability in Northern Italy. Int. J. Environ. Res. 2014, 8, 181-192.

63. Colantoni, A.; Ferrara, C.; Perini, L.; Salvati, L. Assessing Trends in Climate Aridity and Vulnerability to Soil Degradation in Italy. Ecol. Indic. 48, 599-604. [CrossRef]

64. Karamesouti, M.; Detsis, V.; Kounalaki, A.; Vasiliou, P.; Salvati, L.; Kosmas, C. Land-use and land degradation processes affecting soil resources: Evidence from a traditional Mediterranean cropland (Greece). Catena 2015, 132, 45-55. [CrossRef]

65. Munafò, M.; Salvati, L.; Zitti, M. Estimating soil sealing at country scale-Italy as a case study. Ecol. Indic. 2013, 26, 36-43. [CrossRef]

66. Zambon, I.; Benedetti, A.; Ferrara, C.; Salvati, L. Soil Matters? A Multivariate Analysis of Socioeconomic Constraints to Urban Expansion in Mediterranean Europe. Ecol. Econ. 2018, 146, 173-183. [CrossRef]

67. Harte, J. Human population as a dynamic factor in environmental degradation. Popul. Environ. 2007, 28, 223-236. [CrossRef]

68. Kosmas, C.; Karamesouti, M.; Kounalaki, K.; Detsis, V.; Vassiliou, P.; Salvati, L. Land degradation and long-term changes in agro-pastoral systems: An empirical analysis of ecological resilience in Asteroussia-Crete (Greece). Catena 2016, 147, 196-204. [CrossRef]

69. Salvati, L.; Zitti, M. Land degradation in the Mediterranean basin: Linking bio-physical and economic factors into an ecological perspective. Biota J. Biol. Ecol. 2005, 5, 67-77.

70. Pausas, J.G. Changes in fire and climate in the eastern Iberian Peninsula (Mediterranean basin). Clim. Chang. 2004, 63, 337-350. [CrossRef]

71. Schelhaas, M.J.; Nabuurs, G.J.; Schuck, A. Natural disturbances in the European forests in the $19^{\text {th }}$ and $20^{\text {th }}$ centuries. Glob. Chang. Biol. 2003, 9, 1620-1633. [CrossRef]

72. Thompson, J.N. The Geographic Mosaic of Coevolution; University of Chicago Press: Chicago, IL, USA, 2005.

73. Keeley, J.E. Fire intensity, fire severity and burn severity: A brief review and suggested usage. Int. J. Wildland Fire 2009, 18, 116-126. [CrossRef]

74. Salvati, L.; Perini, L.; Sabbi, A.; Bajocco, S. Climate aridity and land use changes: A regional-scale analysis. Geogr. Res. 2012, 50, 193-203. [CrossRef]

75. Colantoni, A.; Mavrakis, A.; Sorgi, T.; Salvati, L. Towards a 'polycentric' landscape? Reconnecting fragments into an integrated network of coastal forests in Rome. Rendiconti Accademia Nazionale dei Lincei 2015, 26, 615-624. [CrossRef]

76. De Meo, I.; Ferretti, F.; Paletto, A.; Cantiani, M.G. An approach to public involvement in forest landscape planning in Italy: A case study and its evaluation. Ann. Silvic. Res. 2017, 41, 54-66. 
77. Moreira, F.; Rego, F.C.; Ferreira, P.G. Temporal (1958-1995) pattern of change in a cultural landscape of northwestern Portugal: Implications for fire occurrence. Landsc. Ecol. 2001, 16, 557-567. [CrossRef]

78. Tomao, A.; Quatrini, V.; Corona, P.; Ferrara, A.; Lafortezza, R.; Salvati, L. Resilient landscapes in Mediterranean urban areas: Understanding factors influencing forest trends. Environ. Res. 2017, 156, 1-9. [CrossRef] [PubMed]

79. Carreiras, M.; Ferreira, A.J.D.; Valente, S.; Fleskens, L.; Gonzales-Pelayo, Ó.; Rubio, J.L.; Ritsema, C.J. Comparative analysis of policies to deal with wildfire risk. Land Degrad. Dev. 2014, 25, 92-103. [CrossRef]

80. Biasi, R.; Colantoni, A.; Ferrara, C.; Ranalli, F.; Salvati, L. In-between Sprawl and Fires: Long-term Forest Expansion and Settlement Dynamics at the Wildland-Urban Interface in Rome, Italy. Int. J. Sustain. Dev. World Ecol. 2015, 22, 467-475. [CrossRef]

81. Salvati, L.; Zitti, M.; Perini, L. Fifty years on: Long-term patterns of land sensitivity to desertification in Italy. Land Degrad. Dev. 2016, 27, 97-107. [CrossRef]

82. Ferrara, A.; Salvati, L.; Sabbi, A.; Colantoni, A. Soil resources, land cover changes and rural areas: Towards a spatial mismatch? Sci. Total Environ. 2014, 478, 116-122. [CrossRef] [PubMed]

83. Salvati, L.; Petitta, M.; Ceccarelli, T.; Perini, L.; Di Battista, F.; Venezian Scarascia, M.E. Italy's renewable water resources as estimated on the basis of the monthly water balance. Irrig. Drain. 2008, 57, 507-515. [CrossRef]

84. Salvati, L.; Zitti, M.; Ceccarelli, T. Integrating economic and environmental indicators in the assessment of desertification risk: A case study. Appl. Ecol. Environ. Res. 2008, 6, 129-138. [CrossRef]

85. Serra, P.; Vera, A.; Tulla, A.F.; Salvati, L. Beyond urban-rural dichotomy: Exploring socioeconomic and land-use processes of change in Spain (1991-2011). Appl. Geogr. 2014, 55, 71-81. [CrossRef]

86. Stephens, S.L.; McIver, J.D.; Boerner, R.E.J.; Fettig, C.J.; Fontaine, J.B.; Hartsough, B.R.; Kennedy, P.L.; Schwilk, D.W. The effects of forest fuel-reduction treatments in the United States. Biosciences 2012, 62, 549-560. [CrossRef]

87. Colantoni, A.; Grigoriadis, E.; Sateriano, A.; Venanzoni, G.; Salvati, L. Cities as selective land predators? A Lesson on Urban Growth, (Un)effective planning and Sprawl Containment. Sci. Total Environ. 2016, 545-546, 329-339. [CrossRef] [PubMed]

88. Kallis, G. Socio-environmental coevolution: Towards an analytical approach. Int. J. Sustain. Dev. World Ecol. 2007, 14, 9-19. [CrossRef]

89. Levy, M.Jr. Modernization and the Structures of Societies; Princeton University Press: Princeton, NJ, USA, 1966.

90. Myrskyla, M.; Kohler, H.P.; Billari, F. Advances in development reverse fertility declines. Nature 2009, 460, 741-743. [CrossRef] [PubMed]

91. Nelson, R.R. Bringing institutions into evolutionary growth theory. J. Evol. Econ. 2002, 12, 17-28. [CrossRef]

92. Pili, S.; Grigoriadis, E.; Carlucci, M.; Clemente, M.; Salvati, L. Towards Sustainable Growth? A Multi-criteria Assessment of (Changing) Urban Forms. Ecol. Indic. 2017, 76, 71-80. [CrossRef]

93. Cuadrado Ciuraneta, S.; Durà Guimerà, A.; Salvati, L. Not only tourism: Unravelling suburbanization, second-home expansion and "rural" sprawl in Catalonia, Spain. Urban Geogr. 2017, 38, 66-89. [CrossRef]

94. Duvernoy, I.; Zambon, I.; Sateriano, A.; Salvati, L. Pictures from the Other Side of the Fringe: Urban Growth and Peri-urban Agriculture in a Post-industrial City (Toulouse, France). J. Rural Stud. 2018, 57, 25-35. [CrossRef]

95. Recanatesi, F.; Clemente, M.; Grigoriadis, S.; Ranalli, F.; Zitti, M.; Salvati, L. A fifty-years sustainability assessment of Italian Agro-forest Districts. Sustainability 2016, 8, 32. [CrossRef]

96. Salvati, L.; Carlucci, M. The economic and environmental performances of rural districts in Italy: Are competitiveness and sustainability compatible targets? Ecol. Econ. 2011, 70, 2446-2453. [CrossRef]

97. Salvati, L.; Gargiulo, V.; Rontos, K.; Sabbi, A. Latent Exurban Development: City Expansion Along the Rural-To-Urban Gradient in Growing and Declining Regions of Southern Europe. Urban Geogr. 2013, 34, 376-394. [CrossRef]

98. Stockdale, A. Contemporary and 'Messy' Rural In-migration Processes: Comparing Counterurban and Lateral Rural Migration. Popul. Space Place 2016, 22, 599-616. [CrossRef]

99. Carbonaro, C.; Leanza, M.; McCann, P.; Medda, F. Demographic decline, population aging, and modern financial approaches to urban policy. Int. Reg. Sci. Rev. 2016. [CrossRef]

100. Discroll, D.A.; Bodea, M.; Bradstockd, R.A.; Keithe, D.A.; Penmand, T.D.; Priced, O.F. Resolving future fire management conflicts using multi-criteria decision making. Conserv. Biol. 2015, 30, 196-205. 
101. Rudel, T.K. Tree farms: Driving forces and regional patterns in the global expansion of forest plantations. Land Use Policy 2009, 26, 545-550. [CrossRef]

102. Galiana-Martín, L.; Montiel-Molina, C. Landscape changes and wildfire behaviour: New fire scenarios in Spain. Landscape 2011, 9, 13.

103. Zambon, I.; Colantoni, A.; Cecchini, M.; Mosconi, E.M. Rethinking sustainability within the viticulture realities integrating economy, landscape and energy. Sustainability 2018, 10, 320. [CrossRef]

104. Colantoni, A.; Marucci, A.; Monarca, D.; Pagniello, B.; Cecchini, M.; Bedini, R. The risk of musculoskeletal disorders due to repetitive movements of upper limbs for workers employed to vegetable grafting. J. Food Agric. Environ. 2012, 10, 14-18.

105. Cecchini, M.; Zambon, I.; Pontrandolfi, A.; Turco, R.; Colantoni, A.; Mavrakis, A.; Salvati, L. Urban sprawl and the 'olive'landscape: Sustainable land management for 'crisis' cities. GeoJournal 2018, 84, 237-255.

106. Zambon, I.; Sabbi, A.; Schuetze, T.; Salvati, L. Exploring forest 'fringescapes': Urban growth, society and swimming pools as a sprawl landmark in coastal Rome. Rendiconti Lincei 2015, 26, 159-168. [CrossRef]

107. Jain, P.; Wang, X.; Flannigan, M.D. Trend analysis of fire season length and extreme fire weather in North America between 1979 and 2015. Int. J. Wildland Fire 2018, 26, 1009-1020. [CrossRef]

(C) 2019 by the authors. Licensee MDPI, Basel, Switzerland. This article is an open access article distributed under the terms and conditions of the Creative Commons Attribution (CC BY) license (http:// creativecommons.org/licenses/by/4.0/). 